\title{
Specific influence of knowledge intensive and capital intensive organizations on collaborative climate and knowledge sharing in SMEs
}

\author{
Viktorija Petrov \\ Faculty of Economics, University of Novi Sad, Novi Sad, Serbia \\ Đorđe Ćelić \\ Faculty of Technical Sciences, University of Novi Sad, Novi Sad, Serbia \\ Zorica Uzelac \\ Faculty of Technical Sciences, University of Novi Sad, Novi Sad, Serbia \\ Zoran Drašković \\ Faculty of Technical Sciences, University of Novi Sad, Novi Sad, Serbia
}

\begin{abstract}
In this paper, the authors discuss knowledge management, with a focus on knowledge sharing. Knowledge sharing is dependent on trust and cooperation, which are elements of organizational culture. One specific aspect of organizational culture is of particular interest for knowledge sharing. This aspect consists of values, beliefs and atmosphere that characterize common mental space accepted by knowledge workers which affect behavior and readiness to share knowledge. This aspect of organizational culture is called collaborative climate and can be described as the 'permeability' of the human infrastructure for knowledge sharing. Collaborative climate in an organization can be considered as an environment that provides support to knowledge workers to create new knowledge that will be translated into a value, which will become competitive advantage of an organization. A questionnaire for assessing two dimensions of the collaborative climate: Organizational Culture and Employee Attitude was used as an instrument in this research. The main research questions in this paper are: 1) Is there a statistically significant difference between attitudes towards collaborative climate of managers and employees? 2) Is there a statistically significant difference between attitudes towards collaborative climate in capital intensive and knowledge intensive organizations? Research hypotheses emerged from the main research questions.

The survey was conducted in order to answer research questions. Data collection was carried out in 2016 throughout the territory of the Republic of Serbia. The sample in this research consisted of 114 managers from 78 randomly selected SMEs from the database of the National Agency for Regional Development. Afterwards, 647 employees were surveyed from those same companies, and in total 761 valid responses were collected. Principal component analysis was applied to the data. In order to check for statistically significant differences, factor scores were tested using Leven's homogeneity test of variance and t-test. Data analysis indicated the existence of statistically significant differences between employee and managers attitudes in their assessment of collaborative climate in capital intensive and knowledge intensive organizations.
\end{abstract}

\section{Keywords}

Knowledge Management (KM), Small and Medium-Sized Enterprises (SME), Knowledge Intensive Organization (KIO), Capital Intensive Organizations (CIO), Collaborative Climate 


\section{Introduction}

The importance of small and medium-sized enterprises (SMEs) in the process of consolidating the economies of countries that are exposed to the processes of transition from industrial economy to the knowledge economy, ownership and social transition is unquestionable. According to the report by the European Bank for Reconstruction and Development (EBRD) for 2016, SMEs account for over $99 \%$ of the total number of enterprises in the countries in which the EBRD is active (European Bank for Reconstruction and Development, 2019). SMEs are the engine of economic development of any country and they account for more than $85 \%$ of new jobs and provided two-thirds of the total private sector employment in the EU in the past 5 years (European Commission, 2019; de Wit and de Kok, 2014).

In the Lisbon Strategy adopted in 2000, the main goal was to make the European Union the most competitive and dynamic knowledge economy in the world by 2020 (European Committee of the Regions, 2019). Bearing in mind that SMEs make up the majority of enterprises, it clearly follows that the measures and policies that have been undertaken to achieve the EU's strategic goal are aimed at SMEs. Thus, in 2005 in the revised Lisbon Strategy, the Council of Europe adopted the "Integrated guidelines and specific areas for priority actions" (European Committee of the Regions, 2019) among which are:

- greater investment in knowledge and innovation,

- unlocking business potential, especially for SMEs.

In 1996 OECD report it was argued that the economies of member states were increasingly based on knowledge and information (Organization for Economic Cooperation and Development, 2019). Knowledge is recognized as the most important resource, as a driver of productivity and economic growth. The interest of the scientific and professional public is focused on understanding the knowledge based economy and its characteristics relative to the traditional economy, the capital based economy.

With the knowledge economy, new topics and questions sprouted in regards to the implications of different characteristics of knowledge as a basic resource, compared to capital as the basic resource of an industrial economy. In response to this challenge, emerged Knowledge Management (KM). Knowledge management has become an important factor in achieving and maintaining competitive advantage. Processes of integrating individuals' knowledge into organizational knowledge, and processes of combining organizational knowledge that leads to the desired performance resulting in competitive advantage of the organization, have become essential. Given that the vast majority of initiatives in these processes depend on knowledge sharing, this becomes the most important aspect within KM.

\section{Knowledge management}

The bulk of papers dealing with KM refer to large enterprises. Applying good experiences from large organizations to SMEs by simply scaling is not a correct approach because SMEs do not have the same characteristics as large enterprises (Sparrow, 2005). In response to this, there is a new theory and practice relating to $\mathrm{KM}$ in SMEs (Durst \& Edvardsson, 2012; Cerchione, Esposito \& Spadaro, 2016).

The first wave of KM was actually management of explicit knowledge, i.e. data and information. This wave has transformed the industrial society into information society. In the information society, the codification of knowledge and its transfer through communication and computer networks was of paramount importance. There is no disagreement in the scientific community about the importance of IT for locating, storing, accessing and sharing explicit knowledge. In a situation when we are buried with data and information, the organization's ability to manage data and information flows and thus ensure the selection of relevant information and data could be considered a competitive advantage. However, the systems for managing explicit knowledge are fairly transparent and relatively easy to replicate. This means that they cannot be the source of a sustainable long-term competitive advantage (Petrov, Trivić \& Ćelić, 2018).

The importance of non-codified knowledge (tacit knowledge) and its diffusion require better understanding of knowledge networks. Man is the only active agent of a non-codified knowledge, which means that man is the basic unit of knowledge networks. It is clear how the capacity of computer networks to transmit codified knowledge is defined, but the question is what impacts the capacity of human knowledge networks to transmit non-codified knowledge? Knowledge networks are social networks, and their effectiveness depends on 
trust among people who make up the network. Unlike the formalized structures in the organization, knowledge networks are informal and difficult to identify because they intertwine with both functions and hierarchy. Less structured work environments give individuals opportunity to creatively solve problems and thus encourage experimentation and innovation (Nica, 2018; Kral, Janoskova, Podhorska, Pera \& Neguriţă, 2019).

\section{Collaborative climate}

Peter Drucker (1999) emphasized that one of the greatest challenges of management in the twentyfirst century would be how to increase the productivity of knowledge workers. Developed countries will retain their advantage only if they improve the productivity of knowledge workers as they have improved the productivity of manual workers in the industrial economy. Productivity is related to norming and it has been defined by the capacity of technological lines in the industrial economy. The productivity of knowledge workers cannot be controlled in this way.

An alternative approach is necessary - an approach where the focus is on the bearer of knowledge and on the context in which knowledge is created and shared, i.e. the focus on collaborative climate. The view that knowledge is embedded and constructed inside social networks has been argued by Nonaka \& Takeuchi (1995). They state that knowledge cannot be processed in the same way as information because it is continually redefined and reconstituted through dynamic and interactive social networks. Knowledge can be shared if there is mutual respect, attention, and understanding (Nonaka \& Takeuchi, 1995; Sveiby, 1997). Exchange of tacit knowledge requires a culture suitable for this type of sharing. Integration of knowledge among communities within organizations is the most dependent on people, and organizational culture (Davenport \& Prusak, 2000).

Organizational culture defines values and beliefs that form an integral part of what we choose to notice and accept. Organizational culture also imposes a common, generally accepted perception of reality about how things look and how they should look (Davenport \& Prusak, 2000). The culture of a group defines willingness and conditions under which an individual would share knowledge with other members of an organization. Knowledge sharing is inseparable from the organizational culture.
$\mathrm{KM}$ literature emphasizes the following concepts: knowledge transfer, knowledge sharing and knowledge transfer barriers (Paulin \& Suneson, 2012). Knowledge sharing is more often in the focus of authors who approach KM at the individual level, while knowledge transfer is the focus of authors who deal with KM at group, or organizational level. It is of paramount importance to understand all three concepts in the context of $\mathrm{KM}$ as well as their interrelation.

In this paper, the authors analyze KM, with focus on knowledge sharing. Sharing of knowledge depends on trust and cooperation, which are considered elements of organizational culture. Sveiby and Simons (2002) emphasize importance of one specific aspect of organizational culture for knowledge sharing. This aspect consists of values, beliefs and atmosphere that characterize a common mental space accepted by knowledge workers which affect behavior and readiness to share knowledge. This aspect of organizational culture is called collaborative climate and described as 'permeability' of the human knowledge sharing infrastructure (Uzelac, Ćelić, Petrov, Drašković \& Berić, 2018; Sveiby \& Simons, 2002; Sveiby, 2007). A collaborative climate in an organization can be considered as an environment that provides support to knowledge workers for creation of new knowledge which could be translated into value and competitive advantage for the organization.

Virtual space called collaborative climate can be divided into levels: the individual level of the employee, the level of the group that makes the closest environment, and the level of the organization that creates the mental context. Having in mind the characteristics of the collaborative climate Sveiby \& Simons (2002) have identified and isolated factors that influence knowledge sharing, trust, and cooperation.

These factors are grouped into four dimensions with five statements and constitute instrument for assessment of collaborative climate, Collaborative Climate Assessment (CCA) Instrument:

- a group of statements describing the attitudes of the respondents, Employee Attitude;

- group of statements describing the behavior of a colleagues closest to the respondent, which refers to the sharing of knowledge, Work Group Support;

- a group of statements describing the behavior of the nearest superior manager, Immediate Supervisor; 
a group of questions that relate to leadership factors outside the respondent's personal closest work environment, Organizational Culture.

\section{Research}

In this paper, the authors aim to:

- assess the level of development of the collaborative climate in SMEs in Serbia and

- examine whether the type of economy to which SMEs belong (knowledge intensive organization - KIO from knowledge based economy or capital intensive organization - CIO from capital based economy) (Petrov et al., 2019) have an impact on the level of development of the collaborative climate.

The goal of the research in this paper is to contribute to better understanding of the organizational characteristics in SMEs which represents powerful driving force for Serbia's economic development. The authors' second goal is to propose directions for the development of collaborative climate in organizations from KIO and CIO segments of SMEs based on the results of this research.

\subsection{Sample}

The research was carried out on data collected during 2016 on the entire territory of Republic of Serbia (Ćelić, 2016). The sample in this research consisted of 114 managers from 78 randomly selected SMEs from database of the National Agency for Regional Development of Serbia. Afterwards, 647 employees from those same companies, were surveyed. In total, 761 valid responses were collected. From CIO segment in total there were $551(72.4 \%)$ respondents and 210 $(27.6 \%)$ were from KIO. There were 102 (13.4\%) top executives, 87 (11.4\%) middle managers, and $572(75.2 \%)$ employees. Out of the total number of respondents, $212(27.9 \%)$ of them were up to 30 years of age, $306(40.2 \%)$ were older than 30 and younger than $41,151(19.8 \%)$ were older than 40 years and younger than 51, and $92(12.1 \%)$ were older than 50 . When it comes to respondents' gender $470(61.8 \%)$ were male and $291(38.2 \%)$ were female. Figure 1 represents demographic characteristics of survey respondents.
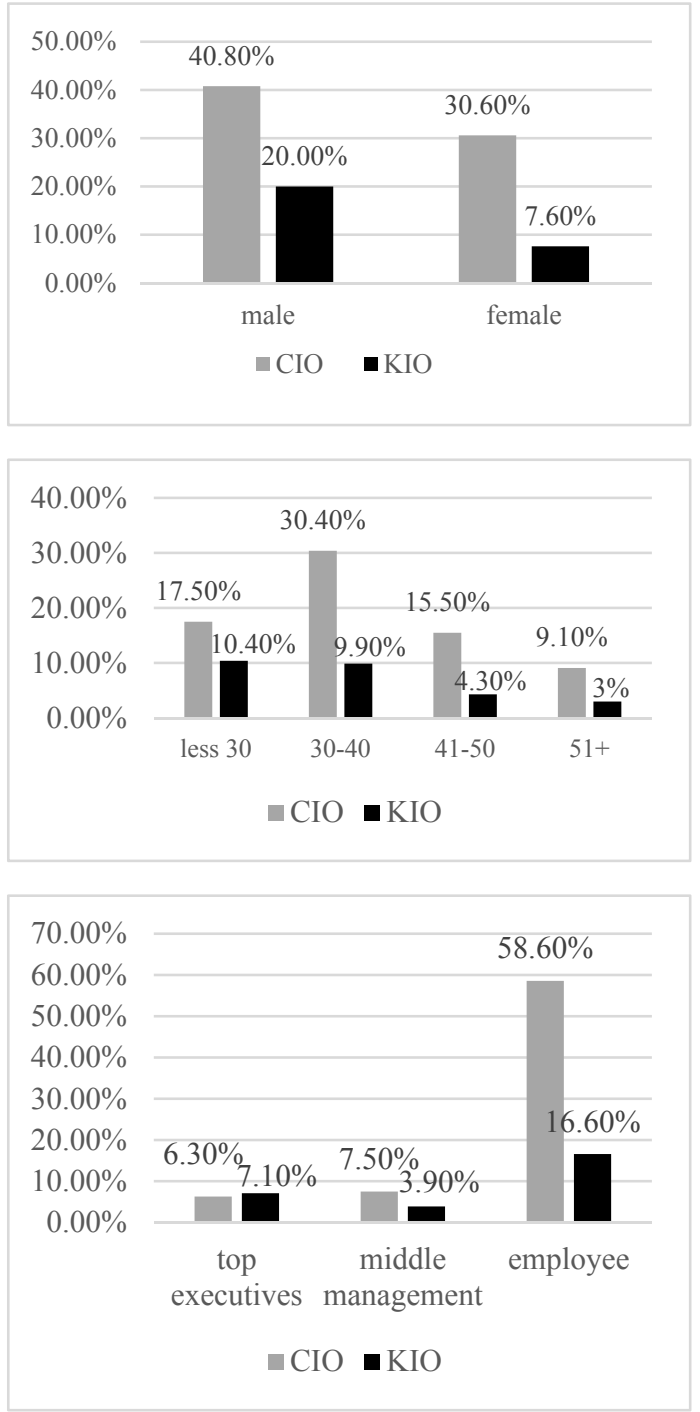

Figure 1 Demographic characteristics of survey respondents

Source: The authors

\subsection{Instrument}

A questionnaire was used as an instrument for the assessment of two dimensions of the collaborative climate in this research. It was adopted from Sveiby and Simons (2002) "Collaborative Climate Assessment" - CCA. Two dimensions of the collaborative climate were investigated: Organizational Culture and Employee Attitude. The questionnaire consisted of ten assertions written in the form of statements with the possibility of different answers in the form of a five point Likert type scale $(5=$ completely agree, $4=$ agree, $3=$ neither agree nor disagree, $2=$ disagree, $1=$ completely disagree). This scale allows for a precise determination of the respondent's attitude towards statements. 


\section{Hypotheses and results}

$\mathrm{H} 1$ : It is possible to assess collaborative climate in SMEs from Serbia using dimensions of CCA instrument.

Principal component analysis of the items that belong to the Collaborative Climate Assessment instrument using Cattel's scree test indicated that the first two components were significant. Varimax orthogonal rotation of the components was used to achieve simpler structure (Table 1).

Table 1 Factor saturation values for items of Collaborative Climate Assessment instrument

\begin{tabular}{|c|c|c|}
\hline Items of Collaborative Climate Assessment instrument & $\begin{array}{c}\text { Factor 1: } \\
\text { Organizational } \\
\text { Culture }\end{array}$ & $\begin{array}{c}\text { Factor 2: } \\
\text { Employee } \\
\text { Attitude }\end{array}$ \\
\hline We are encouraged to say what we think even if it means disagreeing with people we report to. & .803 & \\
\hline We are continuously encouraged to bring new knowledge into the department. & .788 & \\
\hline Open communication is characteristic of the department as a whole. & .745 & \\
\hline Sharing of knowledge is encouraged by the department in action and not only in words. & .704 & \\
\hline The meetings are held on a regular basis to share information. & 649 & \\
\hline $\begin{array}{l}\text { Most of my expertise has developed as a result of working together with colleagues in this } \\
\text { department. }\end{array}$ & & .809 \\
\hline $\begin{array}{l}\text { Combining the knowledge amongst staff has resulted in many new ideas and } \\
\text { solutions for the department. }\end{array}$ & & .782 \\
\hline In the department, information sharing has increased my knowledge & & .714 \\
\hline Sharing information translates to deeper knowledge in this Department & & .696 \\
\hline I learn a lot from other staff in this department & & .543 \\
\hline Eigenvalue after rotation & 3.087 & 2.784 \\
\hline$\%$ variance & 44.71 & 14.01 \\
\hline
\end{tabular}

Reliability of the subscale Organizational Culture evaluated by Cronbach's alpha coefficient is 0.829 , which means that the instrument is reliable. Based on the percentage of variance explained for the first major component $(44.71 \%$, eigenvalue of the first component is 3.087 , (Table 1)) and based on Cattel's scree test, this subscale can be considered one-dimensional, i.e. it has one object of measurement and is homogeneous. Since all items have a significant factor saturation, the validity of this construct is considered satisfactory.

Reliability of the subscale Employee Attitude evaluated by Cronbach's alpha coefficient is 0.805 , which means that the instrument is reliable. Based on the percentage of variance explained for the first major component and based on Cattel's scree test, this subscale can be considered one-dimensional, i.e. it has one object of measurement and is homogeneous. Since all items have a significant factor saturation, the validity of this construct is considered satisfactory.

$\mathrm{H} 2$ : There is statistically significant difference between managers and employees in their assessment of development of certain dimensions of the collaborative climate.
In order to check for statistically significant differences, factor scores were tested using Leven's test for homogeneity of variance and t-test. All results are presented in Table A1. Statistically significant difference between managers and employees was determined in their assessment of the development of dimensions of the collaborative climate. Based on the results the empirical evidence suggests there is highly statistically significant difference in attitudes between managers and employees regarding dimension Organizational Culture $(t=5.453, p<0.01)$. There is statistically significant difference in attitudes between managers and employees regarding dimension Employee attitude $(\mathrm{t}=2.955, \mathrm{p}<0.05)$.

The result above represented the starting point for deeper analysis of $\mathrm{H} 2$ hypothesis with $\mathrm{H} 2.1$ : There is a statistically significant difference between the CIO and KIO sectors of SMEs in their assessment of development of certain dimensions of the collaborative climate. The same test determined statistically significant difference in the attitudes of respondents depending to which sector of the economy they belonged. Significant 
statistical difference in attitudes was determined for Organizational Culture $(\mathrm{t}=4.424, \mathrm{p}<0.01)$.

Since there was a noticeable difference in the attitudes between managers and employees, as well as between respondents from $\mathrm{CIO}$ and $\mathrm{KIO}$ sectors, the authors explored differences in attitudes of managers from CIO and KIO sectors: H2.2: There is statistically significant difference between managers based on the sector they belong to (CIO

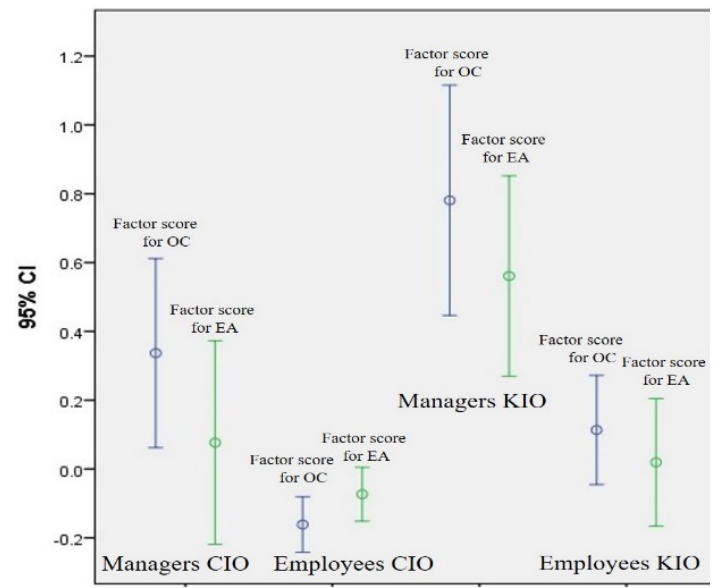

$2 \mathrm{a}$ or KIO) in their assessment of development of certain dimensions of the collaborative climate. Using the aforementioned tests, a statistically significant difference was determined in attitudes of the managers from $\mathrm{KIO}$ and $\mathrm{CIO}$ regarding the Employee Attitude $(t=1.981, p<0.05)$. These differences in attitudes are presented in Figure $2 \mathrm{a}$.

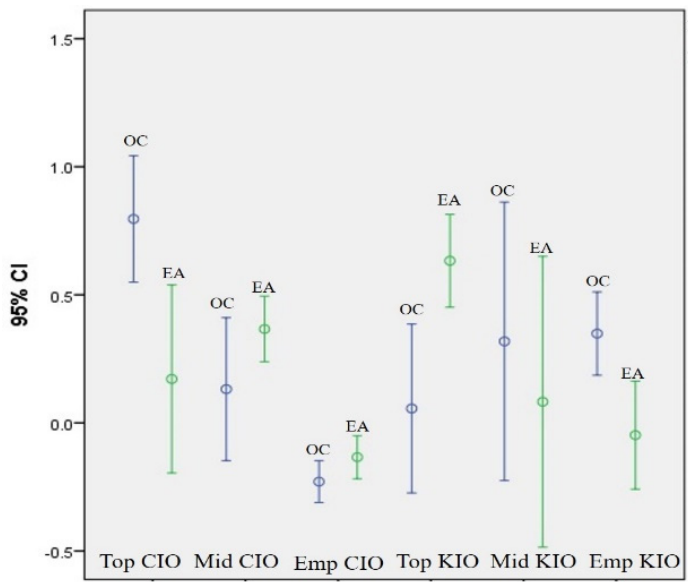

$2 b$

Figure 2 Differences in attitudes of managers (top executives and middle managers) and employees in the observed sectors of SMEs

Source: Authors' calculations

Also, the differences in attitudes between the employees from $\mathrm{CIO}$ and $\mathrm{KIO}$ sectors were explored, with the hypothesis H2.3: There is a statistically significant difference between employees based on the sector they belong to (CIO or KIO) in their assessment of development of certain dimensions of the collaborative climate. Using the appropriate tests, a highly statistically significant difference was determined in the attitudes of the employees from $\mathrm{CIO}$ and $\mathrm{KIO}$ regarding Organizational Culture $(\mathrm{t}=-3.231, \mathrm{p}$ $<0.01)$.

Apart from the mentioned statistical differences, it is important to notice which subgroup of respondents values which dimension more. One can see that respondents from KIO sector value more both the Organizational Culture and the Employee Attitude, while the test indicated statistically significant difference only for Organizational Culture $(t=4.424, p<0.01)$. From Figure 2, it can be concluded that the managers from $\mathrm{CIO}$ and $\mathrm{KIO}$ sectors value differently both dimensions, while the test indicated a statistically significant difference for Employee Attitude $(\mathrm{t}=$ $1.981, \mathrm{p}<0.05)$. The employees from KIO sector value more both dimensions, while the tests indicated statistically significant difference for Organizational Culture $(\mathrm{t}=-3.231, \mathrm{p}<0.01)$.

Looking at Figure $2 b$, the question arises as to whether there are statistically significant differences between managers and employees in the CIO, or the KIO sectors? The following hypotheses were tested: H2.4: There is statistically significant difference in attitudes between managers and employees from CIO sector of SMEs in their assessment of development of certain dimensions of the collaborative climate. Using the appropriate tests, a highly statistically significant difference was determined between attitudes of managers and employees from $\mathrm{CIO}$ regarding Organizational Culture $(\mathrm{t}=3.474, \mathrm{p}<0.01)$. Hypothesis H2.5: There is a statistically significant difference in attitudes between managers and employees from KIO sector in their assessment of development of certain dimensions of the collaborative climate. Highly statistically significant differences were determined between attitudes of managers and employees regarding both dimensions: Organizational Culture $(\mathrm{t}=$ $3.611, \mathrm{p}<0.01)$ and Employee Attitude $(\mathrm{t}=3.135$, $\mathrm{p}<0.01)$. 
Observed differences in attitudes between managers and employees across sectors, as well as between sectors ( $\mathrm{CIO}$ and $\mathrm{KIO}$ ), have led researchers to explore whether there is also difference in attitudes between different levels of management. Do statistically significant differences exist if another level of management is introduced - middle management? The following hypotheses have been formulated: H2.6: There is a statistically significant difference in attitudes between top executives and middle managers from CIO sector in their assessment of development of certain dimensions of collaborative climate. Using the appropriate tests, a highly statistically significant difference was determined between top executives and middle managers regarding Organizational culture $(\mathrm{t}=3.516, \mathrm{p}<0.01)$. H2.7: There is a statistically significant difference in attitudes between middle managers and employees from CIO sector in their assessment of development of certain dimensions of collaborative climate Highly statistically significant differences were determined between middle managers and employees regarding both dimensions, Organizational Culture $(\mathrm{t}=2.845, \mathrm{p}$ $<0.01)$ and Employee Attitude $(\mathrm{t}=4.108, \mathrm{p}<0.01)$.

Differences in attitudes between middle management, top executives and employees were also examined in the KIO sector by testing hypotheses: H2.8: There is a statistically significant difference in attitudes between top executives and middle managers from KIO sector in their assessment of development of certain dimensions of collaborative climate. Statistically significant difference was determined between top executives and middle managers regarding the Employee attitude $(\mathrm{t}=2.302, \mathrm{p}<0.05)$. H2.9: There is a statistically significant difference in attitudes between middle managers and employees from KIO sector in their assessment of development of certain dimensions of collaborative climate. There were no statistically significant differences in between middle managers and employees' attitudes. Differences in attitudes between the two levels of management and employees in the observed sectors are presented in Figure 2b.

Evaluation of the various dimensions of the collaborative climate depending on the position in the organization and on SME sector affiliation is presented in figure $2 \mathrm{~b}$. Observing the results of the research and separating the management into two levels, the question arises as to whether there is a statistically significant difference in the positions among top executives in the CIO, KIO sector. The question is also whether there is statistically significant difference in the positions of middle management in the $\mathrm{CIO}$, KIO sectors.

The following hypotheses were formulated: $\mathrm{H} 2.10$ : There is statistically significant difference in attitudes between top executives from $\mathrm{CIO}$ and $\mathrm{KIO}$ sectors in their assessment of development of certain dimensions of collaborative climate. Statistically significant differences were determined between top executives regarding both dimensions, Organizational Culture $(\mathrm{t}=3.536, \mathrm{p}$ $<0.01)$ and Employee Attitude $(\mathrm{t}=-2.262, \mathrm{p}$ $<0.05$ ). H2.11: There is statistically significant difference in attitudes between middle managers from $\mathrm{CIO}$ and KIO sectors in their assessment of development of certain dimensions of collaborative climate. There were no statistically significant differences between middle managers from $\mathrm{KIO}$ and $\mathrm{CIO}$.

\section{Conclusion}

Results of the analysis within hypothesis H2.10 point to the interesting conclusion that top executives from CIO sector assess Organizational Culture significantly higher than top executives from KIO sector. On the other hand, situation is reversed regarding Employee Attitude assessment. Given that top executives define organizational culture in every organization, this indicates that the top executives from $\mathrm{CIO}$ sector do not focus on Employee Attitude (Figure 2b). This finding is consistent with the type of capital based economy, in which collaboration does not affect organizational performance, as efficiency and efficacy are defined by technology. On the contrary, in knowledge based economy organizational performance is highly dependent on collaboration. Top executives from KIO assess Employee Attitude significantly higher than top executives from $\mathrm{CIO}$ sector.

Analysis of differences in assessment of collaborative climate between managers and employees (hypothesis H2) indicates statistically significant differences regarding both dimensions. Managers assess both dimensions significantly higher than employees (Figure 2a). This finding leads to the conclusion that there is a significant gap in the assessment of collaborative climate between those who create collaborative climate (managers) and those who experience it (employees). These results point to the conclusion that managers need to invest more effort in eliminating identified gap. 
Organizational Culture is a dimension of collaborative climate that reflects general perception of organizational attitude towards sharing knowledge. Results obtained for hypotheses $\mathrm{H} 2.1$ and $\mathrm{H} 2.3$ indicate that there is statistically significant difference in its assessment between employees from KIO and CIO sectors. Employees from KIO sector assess Organizational Culture significantly higher than employees from $\mathrm{CIO}$ sector. These results indicate that managers from CIO sector should invest more effort in the development of Organizational Culture in order to accelerate transition towards knowledge economy.

Comparing assessments of both dimensions by middle management and employees from $\mathrm{CIO}$ and KIO sectors the interesting conclusion follows. There are statistically significant differences between middle managers and employees from CIO sector in their assessment of both dimensions. On the other hand, not only that there are no such significant differences in KIO sector, but those assessments are very close. This points to the existence of a communication problem in CIO SMEs not only between top executives and employees, but also between middle managers and employees. Communication between middle managers and employees is of the highest importance for implementing any strategy. That suggests that management of SMEs form CIO sector have to solve this problem.

Given that the countries from the South-eastern Europe are experiencing similar transition conditions as SMEs in Serbia, the results obtained in this research could benefit SMEs in the whole region.sM

\section{References}

Ćelić, Đ. (2016). Ključni faktori uspešnosti malih i srednjih preduzeća u uslovima tranzicije. Non-published doctoral dissertation. Faculty of Technical Sciences, University of Novi Sad.

Cerchione, R., Esposito, E., \&Spadaro, M. R. (2016). A literature review on KM in SMEs. KM Research \& Practice, 14 (2), 169-177. https://doi.org/10.1057/kmrp.2015.12

Davenport, T.H., \&Prusak, L. (2000). Working Knowledge: How Organizations Manage What They Know. Brighton: Harvard Business Press. https://doi.org/10.1145/347634.348775

de Wit, G., \& de Kok, J. (2014). Do small business create more jobs? New evidence for Europe. Small Business Economics, 42 (2), 283-295. https://doi.org/10.1007/s11187-013-9480-1

Drucker, P. (1999). Management Challenges for the 21 st Century. USA: HarperCollins Publishers Inc,

Durst, S., \& Edvardsson, I. R. (2012). KM in SMEs: a literature review. Journal of KM, 16(6), 879-903. https://doi.org/10.1108/13673271211276173
European Bank for Reconstruction and Development. (2019). Small businesses (SMEs). Retrived April 1 2019, from http://www.ebrd.com/what-we-do/sectorsand-topics/why-small-businesses-matter.html

European Commission. (2019). Entrepreneurship and Small and medium-sized enterprises (SMEs). Retrived April 1 2019, from https://ec.europa.eu/growth/smes.

European Committee of the Regions (2019). The Lisbon Strategy in short. Retrived April 12019 , from https://portal.cor.europa.eu/europe2020/Profiles/Pages/ TheLisbonStrategyinshort.aspx

Kral, P., Janoskova, K., Podhorska, I., Pera, A., \& Neguri ă, O. (2019). The automatability of male and female jobs: Technological unemployment, skill shift, and precarious work. Journal of Research in Gender Studies, 9(1), 146152

https://doi.org/10.22381/JRGS9120197

Nica, E. (2018). Will robots take the jobs of human workers? Disruptive technologies that may bring about jobless growth and enduring mass unemployment. Psychosociological Issues in Human Resource Management, 6(2), 56-61 https://doi.org/10.22381/PIHRM6220184

Nonaka, I., \&Takeuchi, H. (1995). The knowledge-creating company. London: Oxford university press

Organization for Economic Cooperation and Development. (2019). Territorial Development and Human Capital in the Knowledge Economy: towards a political framework. Retrived April 1 2019, from https://www.oecd.org/sti/scitech/1913021.pdf

Paulin , D., \& Suneson, K. (2012). Knowledge Transfer, Knowledge Sharing and Knowledge Barriers - Three Blurry Terms in KM. The Electronic Journal of KM, 10(1), pp 81-91.

Petrov, V., Ćelić, Đ., Uzelac, Z., \& Drašković, Z., (2019). Three pillars of knowledge management in SMEs: evidence from Serbia. International Entrepreneurship Management Journal. https://doi.org/10.1007/s11365-018-00557-2

Petrov, V., Trivić, N., \&Ćelić, Đ., (2018). Assessing sustainability of the southeast european economies. Economcs of Agriculture, 65 (2), 519-529. https://doi.org/10.5937/ekoPolj1802519P

Sparrow, J. (2005). Classification of different KM development approaches of SMEs. KM Research \& Practice, 3, 136-145. https://doi.org/10.1057/palgrave.kmrp.8500053

Sveiby, K. E. (1997). The new organizational wealth: managing \& measuring knowledge-based assets. San Francisco: Berrett-Koehler Publishers.

Sveiby, K.-E., \&Simons, R. (2002). Collaborative climate and effectiveness of knowledge work - an empirical study. Journal of KM. 6(5), 420-433. https://doi.org/10.1108/13673270210450388

Sveiby, K. E. (2007). Disabling the context for knowledge work: the role of managers' behaviours. Management Decision, 45(10), 1636-1655. https://doi.org/10.1108/00251740710838004

Uzelac, Z., Ćelić, Đ., Petrov, V., Drašković, Z., \&Berić, D. (2018). Comparative Analysis of Knowledge Management Activities in SMEs: Empirical Study from a Developing Country. Procedia Manufacturing, 17, 523530. https://doi.org/10.1016/j.promfg.2018.10.092 


\section{Appendix}

Table A1 Summary of Hypotheses Testing

\begin{tabular}{|c|c|c|c|c|c|c|c|}
\hline \multirow[t]{2}{*}{ Dimension } & \multicolumn{2}{|c|}{ Levene's Test } & \multicolumn{5}{|c|}{ t-test for Equality of Means } \\
\hline & $\mathbf{F}$ & Sig & $\mathbf{t}$ & Df & $\begin{array}{l}\text { Sig. (2- } \\
\text { tailed) }\end{array}$ & $\begin{array}{l}\text { Mean } \\
\text { Difference }\end{array}$ & $\begin{array}{l}\text { Std. Error } \\
\text { Difference }\end{array}$ \\
\hline \multicolumn{8}{|c|}{ H2: Attitudes of managers and employees } \\
\hline Dimension 1 - Organizational Culture & 3.293 & .070 & 5.453 & 141.005 & .000 & .62073275 & .11382471 \\
\hline Dimension 2 - Employee Attitude & .129 & .720 & 2.955 & 142.913 & .004 & .33504930 & .11339200 \\
\hline \multicolumn{8}{|c|}{ H2.1: Attitudes of $\mathrm{CIO}$ and $\mathrm{KIO}$ respondents } \\
\hline Dimension 1 - Organizational Culture & 5.541 & .019 & 4.424 & 759 & .000 & .354 & .080 \\
\hline Dimension 2 - Employee Attitude & 10.997 & .001 & 1.399 & 759 & .162 & .113 & .081 \\
\hline \multicolumn{8}{|c|}{ H2.2: Attitudes of managers from $\mathrm{CIO}$ and $\mathrm{KIO}$} \\
\hline Dimension 1 - Organizational Culture & .036 & .850 & 1.620 & 101.044 & .108 & .34938004 & .21570141 \\
\hline Dimension 2 - Employee Attitude & .089 & .767 & 1.981 & 111.304 & .050 & .40730198 & .20560142 \\
\hline \multicolumn{8}{|c|}{ H2.3: Attitudes of employees from $\mathrm{ClO}$ and $\mathrm{KIO}$} \\
\hline Dimension 1 - Organizational Culture & 5.570 & .019 & -3.231 & 645 & .001 & -.274823 & .08505387 \\
\hline Dimension 2 - Employee Attitude & 12.469 & .000 & -1.058 & 645 & .291 & -.09283 & .08777650 \\
\hline \multicolumn{8}{|c|}{ H2.4: Attitudes of managers and employees from $\mathrm{ClO}$} \\
\hline Dimension 1 - Organizational Culture & 2.736 & .099 & 3.474 & 75.872 & .001 & .49832261 & .14344519 \\
\hline Dimension 2 - Employee Attitude & 14.755 & .000 & .979 & 73.548 & .331 & .15011815 & .15329046 \\
\hline \multicolumn{8}{|c|}{ H2.5: Attitudes of managers and employees from KIO } \\
\hline Dimension 1 - Organizational Culture & .167 & 683 & 3.611 & 71.819 & .001 & .66739550 & .18481275 \\
\hline Dimension 2 - Employee Attitude & 1.915 & .168 & 3.135 & 91.935 & .002 & .54127746 & .17266888 \\
\hline \multicolumn{8}{|c|}{ H2.6: Attitudes of top executives and middle managers from $\mathrm{ClO}$} \\
\hline Dimension 1 - Organizational Culture & 6.431 & .013 & 3.516 & 103 & .001 & .6644291 & .18897408 \\
\hline Dimension 2 - Employee Attitude & 4.682 & .033 & -1.075 & 103 & 285 & -.195048 & .18141257 \\
\hline \multicolumn{8}{|c|}{ H2.7: Attitudes of top executives and middle managers from $\mathrm{KIO}$} \\
\hline Dimension 1 - Organizational Culture & 1.832 & .180 & -.838 & 51.335 & .406 & -.2619197 & .31252817 \\
\hline Dimension 2 - Employee Attitude & 9.272 & .003 & 2.302 & 82 & .024 & .5505191 & .23917403 \\
\hline \multicolumn{8}{|c|}{ H2.8: Attitudes of middle managers and employees from $\mathrm{ClO}$} \\
\hline Dimension 1 - Organizational Culture & 4.176 & .042 & 2.845 & 501 & .005 & .36108995 & .12690651 \\
\hline Dimension 2 - Employee Attitude & 22.418 & .000 & 4.108 & 501 & .000 & .50037948 & .12179929 \\
\hline \multicolumn{8}{|c|}{ H2.9: Attitudes of middle managers and employees from KIO } \\
\hline Dimension 1 - Organizational Culture & 19.178 & .000 & -.144 & 154 & .886 & -.030476 & .21188262 \\
\hline Dimension 2 - Employee Attitude & .430 & .513 & .438 & 38.019 & .664 & .1302627 & .29739173 \\
\hline \multicolumn{8}{|c|}{ H2.10: Attitudes of top executives from $\mathrm{ClO}$ and $\mathrm{KIO}$} \\
\hline Dimension 1 - Organizational Culture & 18.030 & .000 & 3.536 & 100 & .001 & .73991972 & .20925845 \\
\hline Dimension 2 - Employee Attitude & 1.058 & .306 & -2.265 & 69.211 & .027 & -.4615682 & .20380964 \\
\hline \multicolumn{8}{|c|}{ H2.11: Attitudes of middle management from $\mathrm{CIO}$ and $\mathrm{KIO}$} \\
\hline Dimension 1 - Organizational Culture & 7.401 & .008 & -.686 & 85 & .495 & -.186429 & .27178142 \\
\hline Dimension 2 - Employee Attitude & 18.201 & .000 & 1.297 & 85 & .198 & .283999 & .21898929 \\
\hline
\end{tabular}

$\triangle$ Correspondence

Viktorija Petrov

Faculty of Economics Subotica, Segedinski put 9-11, 24000

Subotica, Serbia

E-mail: viktorija.petrov@ef.uns.ac.rs 